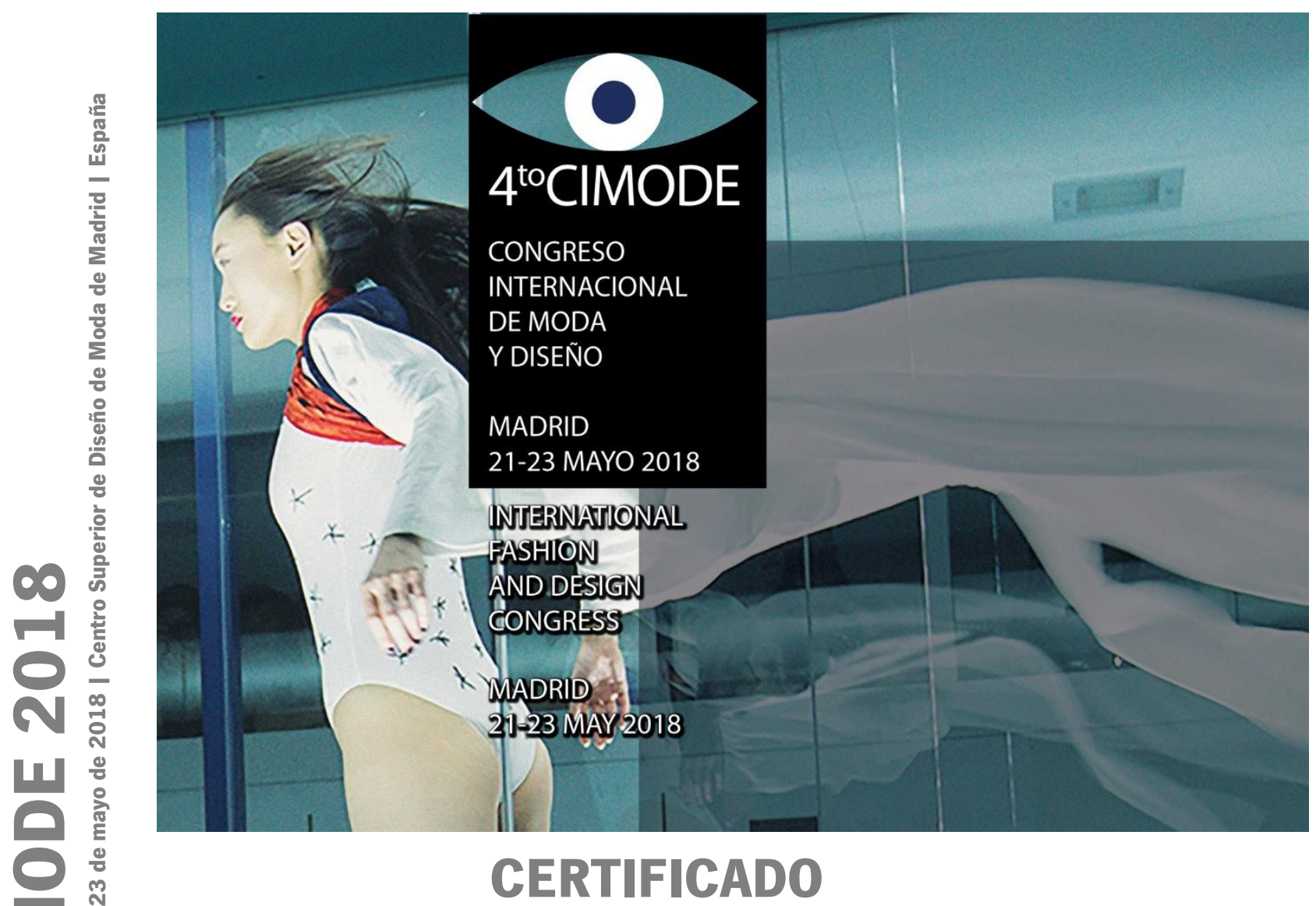

Presidente por el CSDMm Por el presente se certifica que

Manuel Blanco

Decano CSDMM

Presidentes Comité Cientifico

Joana Cunha

Giovanni Maria Conti

Guillermo García-Badell

Presidente fundador del CIMODE

ha formado parte del Comité Científico del

Ana Cristina Broega

CIMODE 2018 - Cuarto Congreso Internacional de P' Org.,

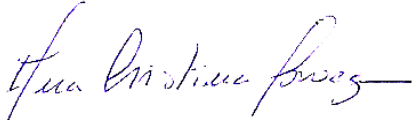
Moda y Diseño, realizado del 21 al 23 de mayo de 2018, Madrid, España 


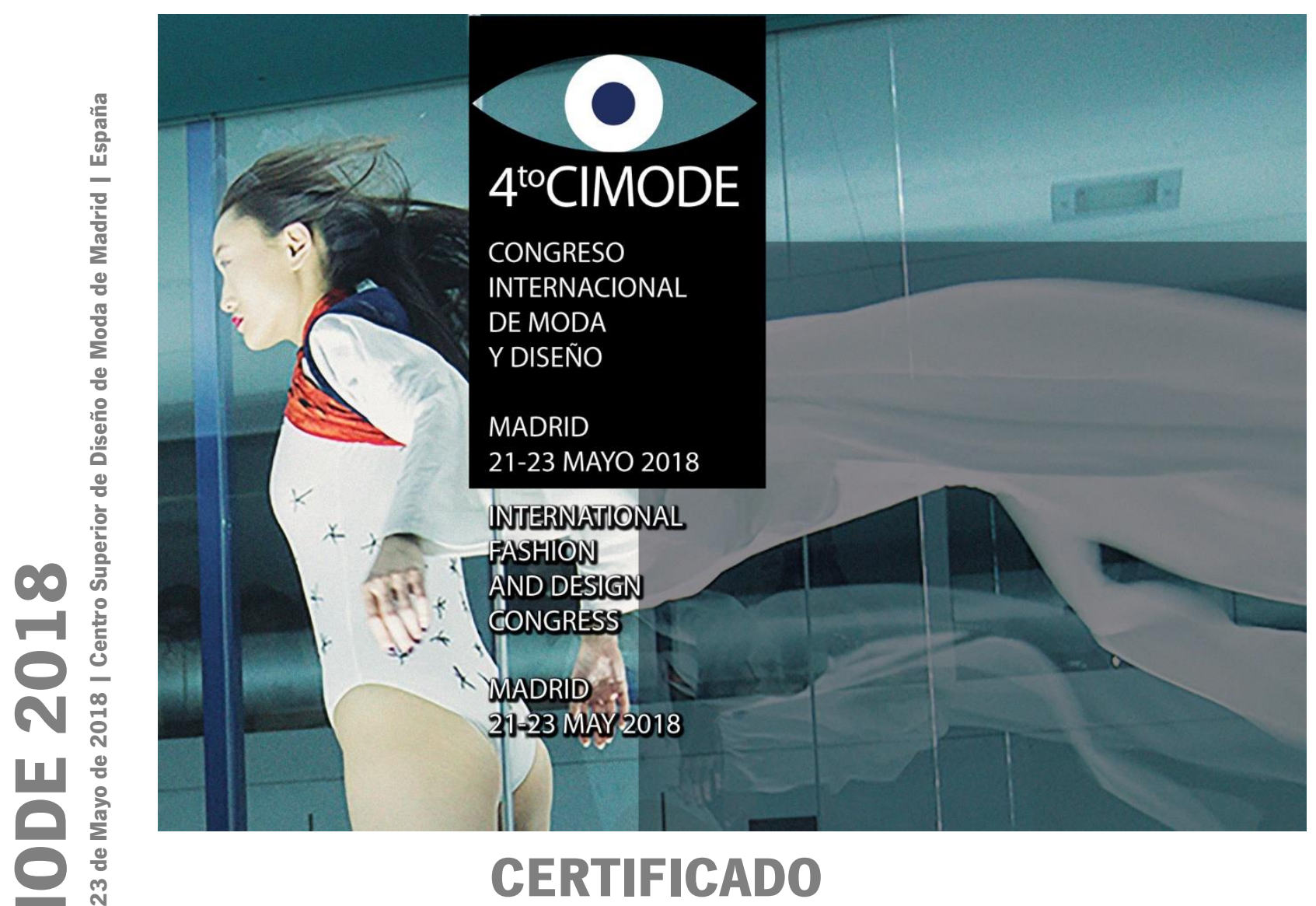

Presidente por el CSDMM Manuel Blanco

Decano CSDMM

Por el presente se certifica que

Decano CSDMM

Presidentes Comité Científico

Giovanni Maria Conti participó como orador invitado

Joana Cunha

Guillermo García-Badell

en la mesa redonda: "Estrategias Proyectuales", con el tema "Cross fertilization"

Presidente fundador del CIMODE

Ana Cristina Broega

en

CIMODE 2018 - Cuarto Congreso Internacional de Moda y Diseño, realizado del 21 al 23 de Mayo de P’org., 2018, Madrid, España

truabliotime foures- 


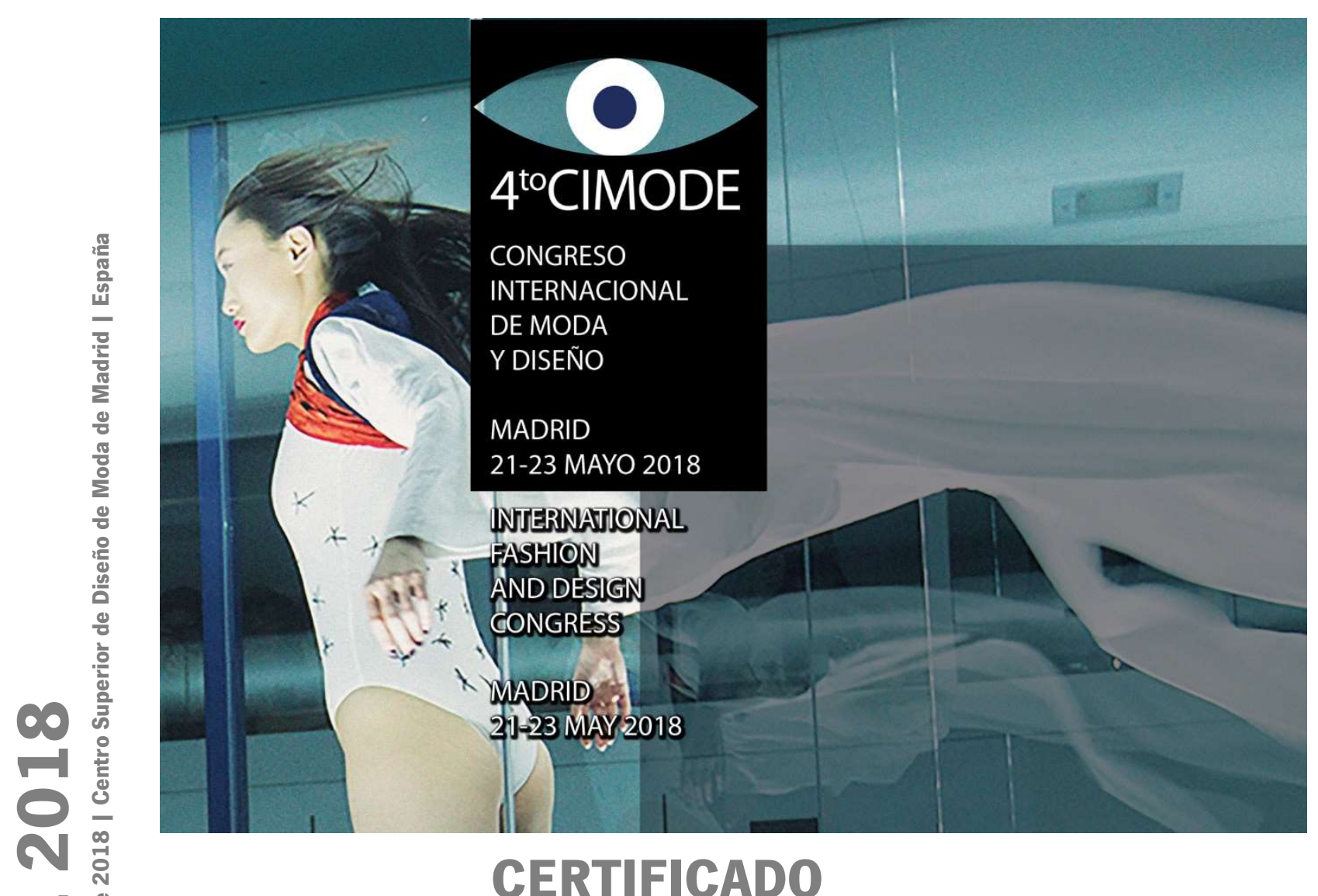

Presidente por el CSDMM Manuel Blanco

Decano CSDMM

Presidentes Comité Cientifico Joana Cunha

Guillermo García-Badell

Presidente fundador del

CIMODE

Ana Cristina Broega

P' Org.,

turablioticue froes-
Por el presente se certifica que el trabajo CONTEMPORARY TEXTILE PRODUCTS. KNITTING AS A FERTILE DESIGN GROUND FOR EXPERIMENTATION WITH 3D TECHNOLOGIES.

de lo(s) autor(es)

GIOVANNI MARIA CONTI

ha sido presentado en

CIMODE 2018 - Cuarto Congreso Internacional de Moda y Diseño, realizado del 21 al 23 de Mayo de 2018, Madrid, España 


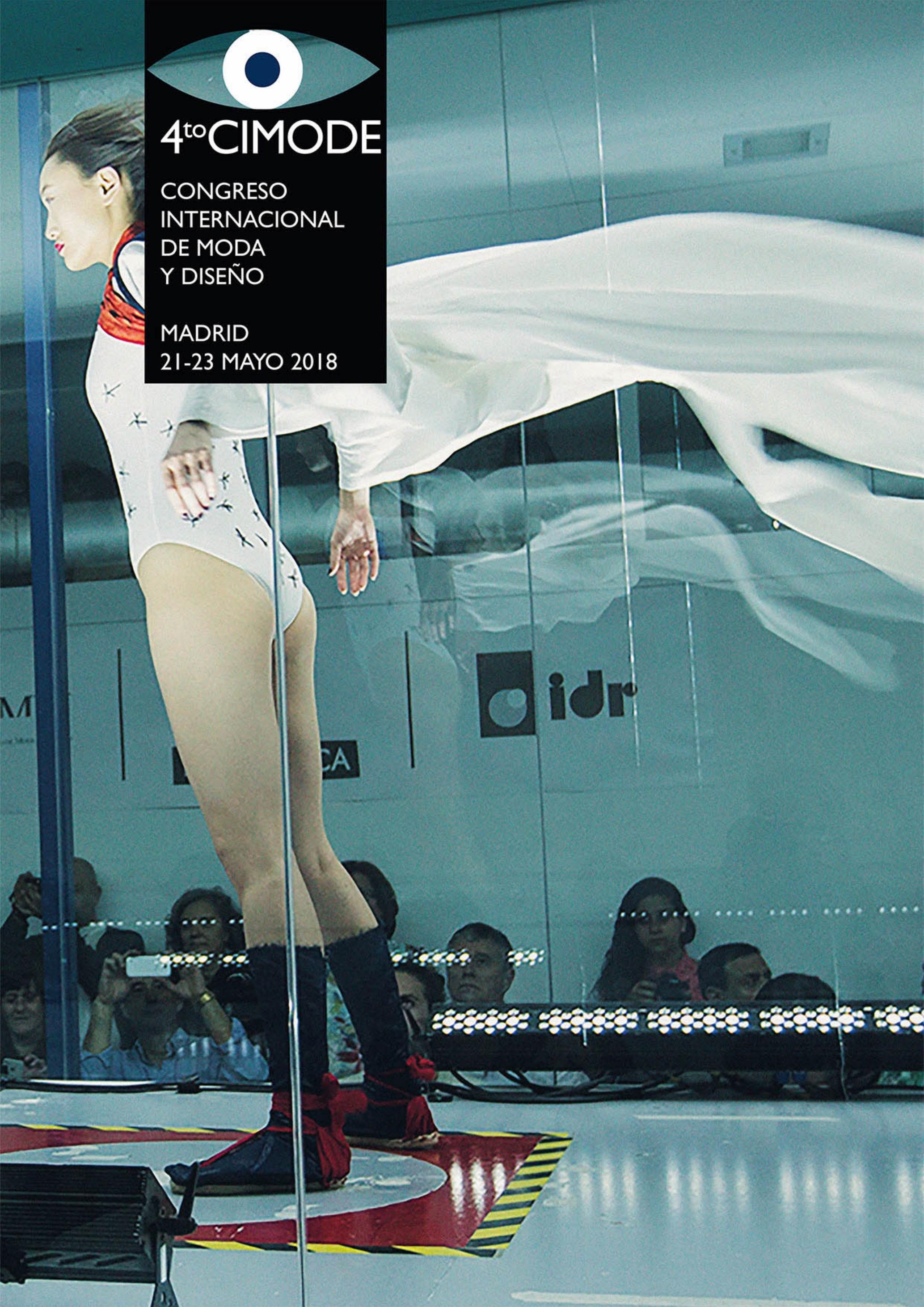


Proceedings CIMODE 2018

40 congresso internacional de moda e design

\section{Editores:}

Ana Cristina Broega (UMinho)

Joana Cunha (UMinho)

Helder Carvalho (UMinho)

Manuel Blanco (CSDMM)

Guillermo García-Badell (CSDMM)

Diana Lucia (CSDMM)

\section{Publicado por:}

Centro de Ciência e Tecnologia Têxtil

Universidade do Minho

Portugal 2018

O conteúdo dos artigos científicos é da inteira responsabilidade dos autores que os assinam.

Imagem Gráfica:

Bernardo Providência

ISBN 978-989-54168-0-6 
O CIMODE 2018 é o 4ํ Congresso Internacional de Moda e Design, realizado de 21 a 23 de maio de 2018 na cidade de Madrid, subordinado ao tema : DISEÑO AL REVÉS.

A presente edição é organizada pelo Centro Superior de Diseño de Moda de Madrid (CSDMM) da Universidad Politécnica de Madrid, em conjunto com o Departamento de Engenharia Têxtil da Universidade do Minho.

O CIMODE configura-se como uma plataforma de intercâmbio da pesquisa em Moda e Design proporcionando o encontro/debate entre pesquisadores, académicos, designers e demais profissionais das áreas da Moda e Design que, através de um diálogo interdisciplinar e intercultural, perspetiva gerar e apresentar novos cenários sobre a atual situação e futuro da Moda e Design.

Sendo um congresso inter e transdisciplinar, o CIMODE procura explorar a Moda e o Design do ponto de vista social, cultural, psicológico, e comunicacional, procurando reunir diferentes abordagens e pontos de vista sobre a prática, o ensino e a cultura do Design e da Moda.

\section{“DISEÑO AL REVÉS"}

No ensino e na prática do design encaramos um futuro onde se impõem novos rumos, com novas oportunidades, ferramentas e tecnologias, mas com uma visão mais próxima das pessoas e das comunidades. Importa olhar para o Design desde outras ancoragens, olhar desde dentro para fora, partindo das comunidades, enquanto núcleos geradores de cultura para o mundo. $O$ design deve ser um processo integrador que lidera a inovação e as mudanças sociais. Esse é o sentido do "design al revés".

Nesta 4a edição contamos com mais de 200 participantes, tendo sido apresentadas 126 comunicações orais e 17 posters de trabalhos de iniciação científica, que representam $64 \%$ do total dos trabalhos submetidos ao congresso.

Nesta edição contemplamos uma edição especial de artigos selecionados em língua inglesa, editada pela CRC/Balkema. Assim esses artigos apresentam-se nesta edição apenas na sua versão resumida, nas secções Resumos curtos e Resumos estendidos.

Em nome de nossas Instituições, do Comité de Organização e do Conselho Científico, nos sentimos honrados com esta importante realização e com a presença de todos os participantes.

Nossos melhores votos;
Ana Cristina Broega

Departamento de

Engenharia Têxtil

Universidade do Minho

\section{Manuel Blanco}

Centro Superior de Diseño de Moda de Madrid Universidad Politécnica de Madrid 
Ana Cristina Broega

Departamento de

Engenharia Têxtil

Universidade do Minho

\section{Manuel Blanco}

Centro Superior de Diseño

de Moda de Madrid

Universidad Politécnica de Madrid
El CIMODE 2018 es el 40 Congreso Internacional de Moda y Diseño, realizado de 21 a 23 de mayo de 2018 en la ciudad de Madrid, bajo el tema: DISEÑO AL REVÉS.

La presente edición está organizada por el Centro Superior de Diseño de Moda de Madrid (CSDMM) de la Universidad Politécnica de Madrid, en conjunto con el Departamento de Ingeniería Textil de la Universidade do Minho - Portugal.

CIMODE se configura como una plataforma de intercambio de investigación en Moda y Diseño proporcionando el encuentro/debate entre investigadores, académicos, diseñadores y demás profesionales de las áreas de la Moda y del Diseño que a través del diálogo interdisciplinar e intercultural permita generar y presentar nuevos escenarios sobre la actual y futura situación de la Moda y del Diseño.

Siendo un congreso Inter/transdisciplinar, CIMODE busca explorar la Moda y el Diseño desde el punto de vista social, cultural, psicológico y comunicacional intentando reunir diferentes abordajes y puntos de vista sobre la práctica, la enseñanza y la cultura del Diseño y la Moda.

\section{“DISEÑO AL REVÉS"}

En la enseñanza y en la práctica del diseño encaramos un futuro donde se impone nuevos rumbos, con nuevas oportunidades, herramientas y tecnologías pero con una visión más cercana si cabe a las personas y las comunidades. Importa mirar hacia el Diseño desde otros anclajes, el Diseño debe ser un proceso integrador que lidere la innovación y los cambios sociales, debe mirar desde dentro hacia fuera, partiendo de las comunidades, como núcleos generadores de cultura, para el mundo, ese es el sentido del "diseño al revés".

En esta 4a edición contamos con más de 200 participantes, habiendo sido presentadas 126 comunicaciones orales y 17 posters de trabajos de iniciación científica, que representan el $64 \%$ del total de los trabajos sometidos al congreso.

En esta edición contemplamos una edición especial de artículos seleccionados en lengua inglesa, editada por la CRC / Balkema. Así estos artículos se presentan en esta edición sólo en su versión resumida, en las secciones Resúmenes cortos y Resúmenes extendidos.

En nombre de nuestras instituciones, del Comité de Organización y del Consejo Científico, nos sentimos honrados con esta importante realización y con su presencia.

Nuestros mejores deseos; 
CIMODE 2018 is the 4th International Congress of Fashion and Design, held from 21 to 23 May 2018 in the city of Madrid, under the theme: DISEÑO AL REVÉS.

This edition is organized by the Centro Superior de Diseño de Moda de Madrid (CSDMM) of the Universidad Politécnica de Madrid, together with the Department of Textile Engineering of the University of Minho.

CIMODE is a platform for research exchange in Fashion and Design, promoting the discussion of ideas between researchers, academics, designers and other professionals in the fields of Fashion and Design. Through an interdisciplinary dialogue and intercultural perspective, CIMODE aims to generate and present new scenarios on the present and future of Fashion and Design.

Being an inter- and trans-disciplinary conference, CIMODE explores Fashion and Design at the social, cultural, psychological, and communication perspective, seeking to bring together different approaches and perceptions on the practice, education and culture of Design and Fashion.

\section{“DISEÑO AL REVÉS”}

In teaching and in the practice of design, we face a future where new paths are imposed, with new opportunities, tools and technologies, but with a closer vision for people and communities. It is important to look at Design from other anchors, Design must be an integrative process that leads innovation and social changes, must look from the inside out, starting from the communities, as generating nuclei of culture, for the world. That is the sense of "DISEÑO AL REVÉS" ("REVERSE DESIGN").

In this 4th edition, we had more than 200 participants, 126 oral presentations and 17 posters of scientific initiation works, representing $64 \%$ of the total work submitted to the congress.

In this edition we contemplate a special edition of selected articles in English language, edited by CRC / Balkema. So these articles are presented in this edition only in their short version, in the sections Short abstracts and Extended abstracts.

On behalf of our Institutions, the Organizing Committee and the Scientific Council, we feel honored with this important achievement and the presence of all participants.
Ana Cristina Broega

Departamento de

Engenharia Têxtil

Universidade do Minho

\section{Manuel Blanco}

Centro Superior de Diseño

de Moda de Madrid

Universidad Politécnica de Madrid

Our best wishes; 


\section{Comissão Executiva | Comisión Ejecutiva}

Universidad Politécnica de Madrid

Presidente: Manuel Blanco

Vice-Presidente: Guillermo García-Badell

Universidade do Minho

Presidente: Ana Cristina Broega

Vice-Presidente: Joana Cunha

\section{Comissão Organizadora | Comisión Organizadora}

Universidad Politécnica de Madrid:

Manuel Blanco, Guillermo García-Badell, Angel Cordero, Diana Lucía Gómez Chacón, Laura Luceño, Mercedes Rodríguez

Universidade do Minho:

Ana Cristina Broega; Joana Cunha; Helder Carvalho; Bernardo Providência; António Dinis Marques, Celeste Sanches (ABEPEM)

\section{Comissão Científica | Comisión Científica}

Universidade do Minho

Presidente: Joana Cunha

Universidad Politécnica de Madrid

Presidente: Guillermo García-Badell

\section{Conceção Gráfica | Concepto Gráfico}

Bernardo Providência

Ángel Cordero

Mercedes Rodríguez

\section{Secretário Geral | Secretario General}

Helder Carvalho

Secretariado

Ángel Cordero

Mercedes Rodríguez

Celeste Sanches 


\section{Comissão | Comisión científica}

\section{Design de Produto \\ Diseño de Producto \\ Product Design}

Ana Cristina Broega - DET UM (PT)

Ana Margarida Fernandes - ESARTIPCB (PT)

Araguacy Filgueiras - UFC (BR)

Ángel Cordero -UPM(ES)

Arturo Dell'Acqua Bellavitis - (IT)

Bernardo Providência - EAUM (PT)

Brezo Alcoceba - ESNE (ES)

Gianni Montagna - FAUL (PT)

Guillermo García-Badell -UPM (ES)

Héctor Navarro -UPM (ES)

Hélder Carvalho DET UM (PT)

Isabel Cristina Gouveia - UBI (PT)

Joana Cunha - DET UM (PT)

Manuel Blanco -UPM (ES)

Maria Alice Vasconcelos Rocha -

UFRPE (BR)

Maria Celeste Sanches -ABEPEM

(BR)

Marizilda dos Santos Menezes -

UNESP (SP-BR)

Mônica Moura - UNESP (SP)

Patricia de Mello Souza - UL(BR)

Patrizia Ranzo - UNINA2 (IT)

Paula Trigueiros EAUM (PT)

Raul Cunca - F Belas-Artes UL (PT)

Regina Sanchez EACH - USP (BR)

Rui Roda (PT)

Silgia Costa EACH - USP (BR)

Teresa Franqueira DCA-UA (PT)

\section{Comissão | Comisión científica}

\section{Ensino e Educação \\ Enseñaza y Educación \\ Teaching and Education}

Alexandra Cruchinho -

IPCB/ESART(PT)

Ana Ramos - IPCB/ESART (PT)

Ángel Cordero-UPM (ES)

Bárbara Pino FAAD-UDP-Santiago

(CL)

Brezo Alcoceba - ESNE (ES)

Cátia Rijo -ESEPL (PT)

Desamparados Pardo Cuenca -

ESDValencia (ES)

Fernando Moreira da Silva - UTAL,

Giovanni Maria Conti - POLIMI (IT)

Joana Cunha - DET UM (PT)

Laura Luceño -UPM (ES)

Madalena Pereira - DCTT UBI (PT)

Manuel Blanco- UPM (ES)

Maria Celeste Sanches -ABEPEM

(BR)

Mara Rubia Sant'Anna - UDESC (SC-

BR)

Maria da Graça Guedes - DET UM

(PT)

Maria de Fátima da S. Costa G. de

Mattos - CUML/RP (SP BR)

Marly Menezes - FASM (SP - BR)

Mercedes Rodríguez - UPM (ES)

Patricia de Mello Souza - UL(BR)

Rui Miguel - DCTT UBI (PT) 


\section{Comissão | Comisión científica \\ Marketing e Consumo \\ Marketing y Consumo \\ Marketing and Consumption}

André Robic - IBModa (BR)

António Dinis Marques-UM(PT)

Carlos Alberto Miranda Duarte -

IADE (PT)

Guillermo García-Badell - UPM (ES)

Héctor Navarro - UPM (ES)

Luiz Salomão Ribas Gomez - UFSC,

(BR)

José Ferro Camacho - IADE (PT)

Maria Carolina Garcia - UAM (SP-BR)

Mário de Araujo - UM (PT)

Mercedes Rodríguez - UPM (ES)

Olga Pépece - UEM (BR)

Valter Cardim - IADE, (PT)

\section{Comissão | Comisión científica}

Moda e Comunicação

Moda y Comunicación

Fashion and Communication

Alessandra Vaccari - Università IUAV

di Venezia (IT)

Ana Jiménez - UPM (ES)

Ana Claudia Mei Alves de Oliveira -

PUC (SP -BR)

Carlos Figueiredo- FAUL (PT)

Fausto Viana - ECA-USP (SP -BR)

Kathia Castilho - ABEPEM (BR)

Laura Luceño - UPM (ES)

Manuel Blanco- UPM (ES)

Mara Rubia Sant'Anna - UDESC (SC-

BR)

Marcelo Martins - UFRPE (PE-BR)

Mercedes Rodríguez - UPM (ES)

Moisés Lemos Martins - DCCOM UM

(PT)

Nelson Pinheiro - IADE-UL (PT)

Renata Pitombo Cidreira - UFBA (BR)

Rossana Gaddi - POLIMI (IT)

Sandra Rech - (UDESC (SC-BR)

Silvana Mota Ribeiro - DCCOM UM

(PT)

Solange Riva Mezabarba UFF (SP-BR)

Solange Wajman - UNIP (SP-BR)

Zara Pinto Coelho - DCCOM UM (PT) 


\section{Comissão | Comisión científica}

Moda, Identidades e Culturas

Moda, Identidades y Culturas

Fashion, Identities and Cultures

Bárbara Pino FAAD-UDP-Santiago

(CL)

Brezo Alcoceba - ESNE (ES)

Cristiane Mesquita - UAM (SP-BR)

Diana Lucía Gómez-Chacón - UPM

(ES)

Elisabeth Lorenzi Fernandez - UNED

(ES)

Francisca Mendes -UFC (BR)

Helena Pires- DCCOM-UM (PT)

Herbert González - UPM (ES)

Joana Bosak de Figueiredo (UFRGS-

$B R)$

Laura Luceño - UPM (ES)

Laura Zambrini - FADU-UBA (AR)

Manon Salles - (EBA-UFRJ) (BR)

Marcia Mello - UNIFACS (BA-BR)

Maria Cristina Volpi Nacif - EBA/UFRJ

(BR)

Maria Claudia Bonadio - SENAC/SP

(BR)

Maria do Carmo Teixeira Rainho

(Senai-Cetiqt -BR)

Maria Eduarda Araujo Guimarães -

SENAC/SP (BR)

Pedro Bessa - DCA-UA (PT)

Rafaela Norogrando - UBI / IPV (PT)

Rita Ribeiro - ICS-UM (PT)

Tula Fyskatoris CPS (PUC-SP-BR)

Zara Pinto Coelho - DCCOM UM (PT)

Valter Cadim - IADE, (PT)

\section{Comissão | Comisión científica}

Sustentabilidade em Moda e Design
Sustentabilidad en Moda y Diseño
Sustainability in Fashion and Design

Ana Cristina Broega - DET UM (PT)

Ana Mery De Carli - UCS, (RS- BR)

Anne Anicet Ruthschilling - Uniritter

(BR)

Carla Morais - FAUL (PT)

Cristina Figueiredo - UTAL (PT)

Desamparados Pardo Cuenca -

ESDValencia (ES)

Fernando Moreira da Silva - UTAL, (PT)

Guillermo García-Badell - UPM (ES)

Héctor Navarro - UPM (ES)

Patricia de Mello Souza - UL(BR)

Silgia Costa EACH - USP (BR)

Sirlene Costa - USP (BR)

Suzana Barreto Martins - UEL (BR) 


\title{
CONTEMPORARY TEXTILE PRODUCTS. \\ KNITTING AS A FERTILE DESIGN GROUND FOR EXPERIMENTATION WITH 3D TECHNOLOGIES.
}

\author{
GIOVANNI MARIA CONTI \\ Department of Design, Politecnico di Milano, giovanni.conti@polimi.it
}

\begin{abstract}
This paper sets out to provide an overview of the current state of the art in design for the creation of industrial objects that take advantage of the latest innovations regarding the electronic $3 D$ knitting processes.

The analysis stems from a desire to illustrate the great importance of fabrics for technical applications and of design for industrial textile products.

Specifically, it focuses on the evolution of two-dimensional and three-dimensional fabrics as well as on three-dimensional knitting or smart knitting technologies.

The issue is explored in relation to the difference between $3 D$ knitting and $3 D$ weaving technologies with the aim of demonstrating the broad scope of application in different areas of design, no longer pertaining to fashion and clothing alone.

The paper will conclude by showing that fabrics, especially those produced by smart knitting, hold great promise and advantages not only in the field of clothing but also in the field of industrial design in terms of both performance and production processes.
\end{abstract}

Keywords: 3D knitting, 3D weaving, smart knitting, knitted fabrics, technological innovation, textile materials

\section{Introduction}

When the materials and technologies used in design are examined, it may be noted that textiles are frequently taken into consideration only for projects in the furnishing or clothing sectors; a rather marginal role considering the wide range of product markets and sectors that exist today.

Only in certain projects do textiles play a more functional role; indeed, they exhibit great potential and characteristics which other materials (such as polymers, metals, etc.) do not and cannot have. Nevertheless, the first great obstacle encountered in designing with textiles is that studying and designing their behaviour and predicting their performance often turns out to be a costly, complex process. This is because currently available technologies are all geared towards a traditional use of textiles, while few firms have the capacity to invest in order to attempt to modify existing technologies and making them more competitive with a view to broadening the market for textiles by incorporating them into various industrial sectors.

The search for textiles with superior technical capacities has led to the creation of three-dimensional textiles; this 3D alternative is carving out a space for itself on the design scene as it tends to use new materials and seeks to advance the use of textiles in hitherto unexplored fields. This search has produced many positive outcomes in spite of the fact that it is difficult to invest in these new manufacturing technologies. 
The textile field, too, is therefore seeking to evolve and, given its characteristics, is perhaps the area of research which, more than any other, lends itself to bridging the gap between the world of aesthetics and that of functionality.
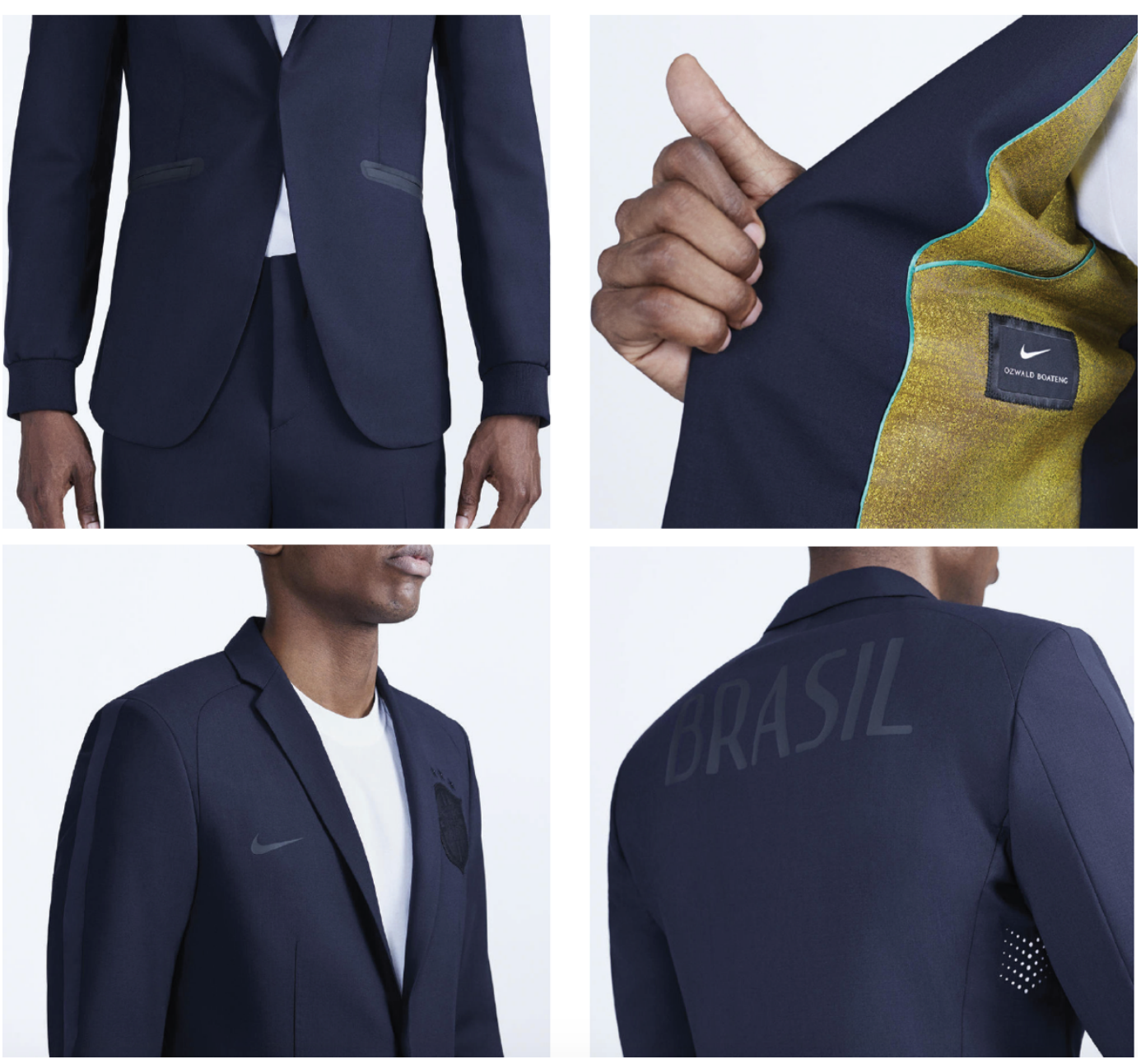

Figure 1: Details of the Nike "N98 Track Jacket" design for the CBF in collaboration with the designer and tailor Ozwald Boateng

Aesthetics and functionality should not necessarily be considered separate from each other; on the contrary, the greatest promise in the world of textiles lies precisely where it can push in this twofold direction. On today's contemporary textile scene, the drive towards innovation comes thanks to three-dimensional textiles which are expanding their range of applications, require greater attention and offer designers more options and choice.

\subsection{Technical textiles}

The sector represented by technical textiles is the one which shows the most rapid growth within the more general industrial textile sector, accounting for around $19 \%$ of total global consumption of textile fibres used in all fields (Byrne 1997 in Handbook of Technical Textiles, Horrock 2000).

The challenge posed by technical textiles consists in the need not only to understand and apply the principles of textile science and technology in order to provide primarily technological solutions but also and above all to investigate, in parallel, the areas in which they will be applied. For example, in order to apply geotextile fabrics, it will be necessary to have knowledge in the civil engineering field, or manufacturers of technical medical textiles will have to talk to the doctors and nurses who will be the end users of the finished product. 
This approach, which is typical of design and defined as cross-fertilisation between areas of scientific knowledge ${ }^{1}$, will intensify the design challenge and allow designers to experiment more.

In Textile Terms and Definitions (published by the Textile Institute ${ }^{2}$ ), technical textiles are defined as "technical materials and products manufactured primarily for their technical and performance properties rather than their aesthetic or decorative characteristics."

This description, however, leaves much open to interpretation, especially in view of the rapid growth which modern textile products that combine decoration with functionality are experiencing.

For many years, the term industrial textiles was used to define any textile products designed to be applied in the various fields of clothing, furniture, furnishing and interior design. Nowadays this would seem to be no longer adequate, especially if one considers the development of the textile products themselves. Today we are dealing with performance textiles, functional textiles, engineered textiles, high-tech textiles, which are often used in different contexts. For example, performance textiles are often related to the world of sportswear, despite the fact that they have and are related to a precise meaning ${ }^{3}$.

\subsection{D textiles}

It is in the area of technical textiles that three-dimensional textiles are being developed for the first time. Textiles have also entered the field of composite materials, or - simply - composites, that is, materials consisting of at least two distinct phases: a continuous phase, called the matrix, and a dispersed phase, called the reinforcement. The result is the combination of the characteristics of the two materials to obtain a new one which has superior properties to those of each of the two initial components. Various kinds of $3 \mathrm{D}$ textiles exist. The first is based on the technology with which the textile has been created and therefore on its interior structure (Khokhar classification), while the second is based on the forms that can be obtained from the various three-dimensional textiles, as set out in Table 1.

\begin{tabular}{|c|c|c|}
\hline Structure & Architecture & Form \\
\hline Solid & $\begin{array}{c}\text { Multilayer } \\
\text { Non-interlacing } \\
\text { Interlacing }\end{array}$ & $\begin{array}{r}\text { Compound structure, with regular or tapered } \\
\text { geometry }\end{array}$ \\
\hline Hollow & Multilayer & $\begin{array}{c}\text { Uneven surfaces, tunnels on different levels in } \\
\text { different directions }\end{array}$ \\
\hline Shell & $\begin{array}{c}\text { Single-layer } \\
\text { Multilayer }\end{array}$ & Spherical shells or "open box" shells \\
\hline Nodal & $\begin{array}{c}\text { Multilayer } \\
\text { Non-interlacing } \\
\text { Interlacing }\end{array}$ & Tubular nodes and solid nodes \\
\hline
\end{tabular}

Table 1: Structures of 3D textiles and textile architectures

Three-dimensional textiles are defined as those which have a third dimension in the thickness direction. Indeed, in 3D textiles, the thickness or dimension along the $z$ axis can be considered

${ }^{1}$ Conti G.M., Cross Fertilization: un approccio al progetto per la moda, Mondadori Università, ebook, Milan, 2012.

2 The Textile Institute is a professional body founded in 1910, Its headquarters are in Manchester, UK. It is concerned with textile fibres, clothing and footwear and has an academic research and development department.

${ }^{3}$ It should be remembered that these different terms may also take on different nuances of meaning when translated into different languages. 
substantial in relation to the longitudinal and transversal dimension on the $\mathrm{x}$ and $\mathrm{y}$ axes respectively (Badawi, 2007). ${ }^{4}$

Given a definition of the term, it is thus possible to classify the different types of 3D textiles according to their interior structure. Based on Khokhar's classification (1998), five categories of three-dimensional textiles can be identified.

- Interlaced 3D fabric, consisting of the conventional 2D weaving process to interlace the two sets of yarns which are orthogonal to each other (warp and weft) with the addition of a third set of yarns which act as a "binder" and which extend through the thickness (in the $Z$ direction).

- 2.5D fabric (polar fleece), consisting of the conventional 2D weaving process, using three sets of yarns (back warp, fleece warp and fleece weft) to create the polar fleece fabric.

- Non-interlaced 3D fabric, consisting of the conventional 2D weaving process with three sets of yarns to produce a non-interlaced fabric with yarns in the directions of the weft and warp and through the thickness.

- Fully interlaced 3D fabric. The process of 3D shuttle weaving designed to interlace three sets of yarns which are orthogonal to each other. The shed of the weave is present both vertically and horizontally. This produces a fully interlaced three-dimensional fabric in which all three sets of yarns are bound orthogonally to each other, which is possible with a machine designed specifically for 3D weaving.

- Non-woven fabric. A three-dimensional fabric which creates thickness as it connects three sets of orthogonal yarns but without weaving, knitting or braiding processes. The fabric is held together by a special, usually mechanical bonding process.

These fabrics have a very broad field of application; they have made their main appearance in the worlds of fashion and furniture yet are present in many other sectors, from the automotive industry to sportswear, all the way to more technical applications such as inserts in objects with various functions or as preforms for composites.

We are familiar with some of these materials and use them daily: for instance, fleece, commonly used for sweaters, jackets and blankets, has the characteristic of having its own "open" third dimension, making it extremely soft and warm to the touch.

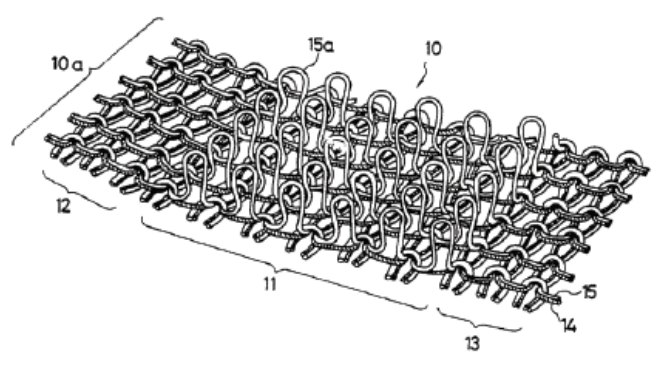

Figure 2: Diagram of polar fleece structure

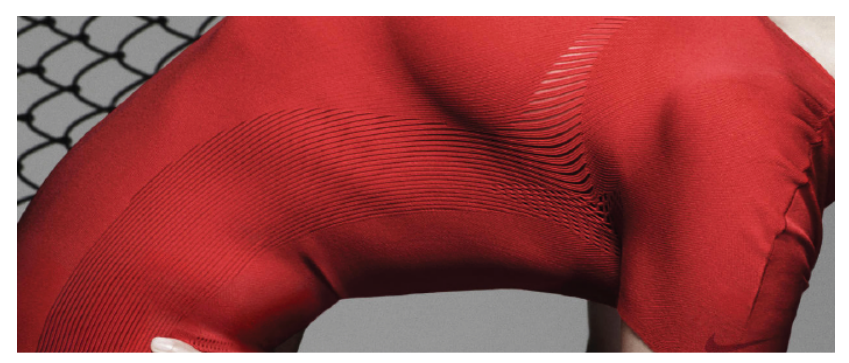

Figure 3: Whole garment sports jersey

Whole garments can be used as medical garments: the technology is often used in the manufacture of gloves, knee-length stockings, knee supports and compression stockings. They are custom designed for

\footnotetext{
${ }^{4}$ Other definitions exist beside the one cited here. For example: "single fabric systems, the constituent yarns of which are supposedly disposed in three mutually perpendicular plane relationships." (Behera \& Mishra, 2008).

"A structure that has a substantial dimension in the thickness direction formed by superimposed layers of fabric or yarns." (Chen, 2011).
} 
users with specific difficulties in certain points of the body, and being seamless they ensure the necessary comfort for the success of the treatment or sporting performance.

\section{Weaving processes}

Until now we have discussed textiles, their variety and the various fields of application in which they are used. Now we will examine the technological processes involved in the weaving of these textiles.

Various technologies exist today to produce textiles which differ greatly from each other and are each suitable for well-defined applications. Thus we have orthogonal fabrics, also termed shuttle-woven fabrics; warp-knitted fabrics, weft-knitted fabrics or in tulle, cohesive or non-woven fabrics, fabrics obtained with hybrid technologies, that is, with the combination of different technologies. The number of types of fabrics that can be obtained is therefore greater than ever, to a large degree because the combinations of yarns are more varied than ever: indeed, synthetic fibres lend themselves to being blended with natural fibres, thereby giving the fabric specific effects of resistance, toughness or sheen, as well as the virtue of specific technical characteristics.

\subsection{Technical characteristics of knitted garments and textiles}

In order to create an orthogonal or shuttle-woven fabric, two fundamental elements are necessary. These are, specifically, the warp (or chain), consisting of parallel threads and the weft, made up of threads arranged transversely to the weft. It is clear that textiles obtained using different methods are distinguished from each other above all in terms of extensibility.

Unlike shuttle-woven fabrics, knitted fabrics do not have a warp and weft but a single thread which passes through the needles creating small linked rings, the so-called "stitches" or "wales".

There are two technologies for their production, which can be distinguished according to the configuration of the basic knitting unit: weft knitting technology and warp knitting technology.

To make a comparison with hand knitting, knitting needles produce warp knitting, whereas crochet work is an example of weft knitting.

The production of knitted fabrics takes place on looms and machines which, by working essentially in different ways, give them their specific features for their end use.

The indispensable element for their production is the knitting needle which enables the formation of curvilinear knitting patterns consisting of stitches which extend in a transverse or vertical direction.

The needles fitted to knitting machines may be of different types depending on how the machine works. There is a range of wearable products that come under the product category of knitwear, from knitted underwear to outerwear, from corsetry to hosiery. What mainly distinguishes knitwear production is the machines used as well as the type of finished garment, and assembly of the knitted fabrics. The basic distinction is between cut and sewn knitwear and full-fashioned knitwear.

Several machines and looms are used to manufacture knitwear fabrics; the position within the textile product of the various kinds of knitwear is characterised by the types of machines and looms used. The distinction between machines and looms is determined by how the needles work. On machines the needles move individually and are able to pick up the yarn (maglie raccolte). On looms the needles work cumulatively and need to be fed the yarn (maglie gettate). The stitches are formed with the yarn which passes horizontally over the needles, giving rise to the term weft knitting; the stitches are formed one after the other with the passage of the carriage with the yarn. For weft knitting, in contrast, the yarn works longitudinally, the number of yarns arranged is the same as the number of needles which form the stitches simultaneously. 


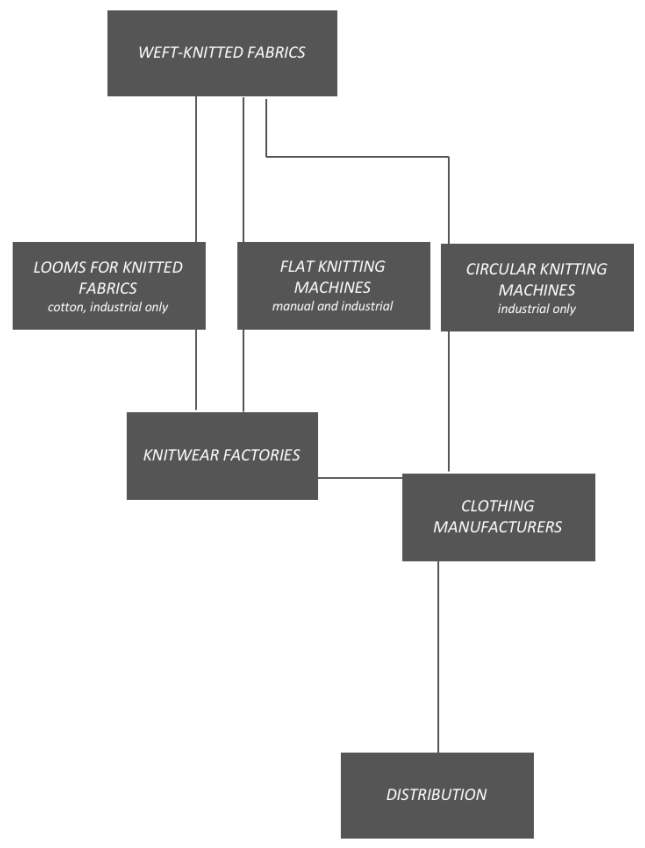

Figure 4: Diagram of supply chain for knitted textiles

The basic classification of knitted fabrics that can be produced on the various types of machines available (on flat machines and looms and on circular machines and looms) is the following:

Plain knit or simple jersey fabrics obtained on a single needle bed, that is, with a single series of needle;

Ribbed knit or double jersey fabrics obtained with two series of needles which cross each other while working together with the passage of the carriage and will thus be offset from each other;

Interlock fabrics obtained with two series of facing needles which work alternately (the needles are selected by means of the long-butt and short-butt needle selector cams);

Links-links fabrics with a series of double-ended needles (machines set up for this type of knitting are in fact called links-links machines) that move on two adjacent needle beds on the same plane: the weave has alternating rows of face and back stitches.

\subsection{D knitting and its potential}

Looking at available technologies is essential if we are to have the right tools for the project. Understanding what a given machine can and cannot do and understanding the limitations and resources of a certain technology is the necessary step towards an informed design process.

While the processes of manufacturing and assembly of knitted garments on cotton looms and flat machines are performed entirely by specialised firms called knitwear factories, fabrics produced on circular machines, incorrectly termed jersey fabrics by those in the industry, can be assembled both by knitwear factories or by following the process of assembling woven fabrics within clothing manufacturing firms. A large textile sector specialising in the production of knitted fabrics for cutting and sewing exists; we find these fabrics in shops in the form of garments ranging from the simplest of $t$-shirts to evening wear. This type of fabric figures strongly in the collections of all luxury brands as it is much cheaper compared with full-fashioned or ready-made knitted garments.

Naturally this comparison is made while taking into consideration garments that are equivalent in terms of weight, fabric and fibre used. What drastically inflates the price of full-fashioned knitwear, 
as it is called in the industry, is the assembly process. All of the shaped sections of fabric are assembled by hand with the linking machine.

Shaped knitwear assembled with the linking machine is termed full-fashioned knitted outerwear, and is high-quality knitwear requiring great skill to manufacture precisely because of the manual dexterity and time required for its assembly. As a result, the most recent technological development in the knitwear area has been that of the full-fashion knitted garment. Complete garments with a total absence of stitching are manufactured on flat knitting machines specifically to overcome the obstacle of the high assembly cost.

The two main manufacturers of industrial electronic flat knitting machines, Shima Seiki (Japan) and Stoll (Germany), which have historically shared $90 \%$ of the global market for flat knitting machines almost equally between themselves, have developed machines that produce an entire knitted garment from the edge to the back and from the front to the sleeves which comes off the machine already assembled and completely stitchless and with reductions where the garment must tighten in order to adhere to the body in an optimal fashion.

Each machine operates at a given fineness ${ }^{5}$, that is, its needles can work yarns with diameters, or yarn counts, of greater or lesser thickness. It is important to understand that if a machine can work an extremely fine thread, it will not be able to do so with thicker threads, and vice versa. Solutions can be found, however, if the fabric requires the use of thread of different thicknesses, by passing several thin threads into one single larger needle. The choice of the fineness of the machine that is to be used determine how thick or fine the garment produced is. Furthermore, different types of machines exist, enabling the creation of garments with different characteristics.

\subsubsection{D preforms}

By analysing forms and their development it is possible to set up the machine so that it creates threedimensional preforms which, once they have come off the machine, can be closed with one or few stitches. This process is extremely useful, for example, in the creation of coverings or linings. Yet it is also useful when, instead of creating a whole garment, only a few connection points are analysed. The figure below shows a garment devised by Stoll which brings together the various technologies that can be obtained from its machines. This balaclava represents an excellent example of optimisation of technologies on a product.

\subsection{D knitting and its potential}

The structures that can be obtained are as many and varied as the processes that enable them to be achieved. A general classification allows at least three of them to be identified:

- manufacture of fabrics with high thickness by overlaying several layers of yarns;

- total interlacing of the fibres, in both the vertical and horizontal direction, by means of a specific shed opening system;

- creation of shaped textiles (Hu, 2008).

Nevertheless, this does not give a clear overview of the configurations that it is possible to obtain. A classification which differentiates between the available manufacturing technologies provides a clearer

\footnotetext{
${ }^{5}$ The number of needles on a single needle bed contained within a specific unit of length. This measurement of fineness is required in order to understand a priori how thick or fine the knitted garment will be. The yarn count is therefore closely related to the type of machine that is intended to be used.
} 
picture. Based on such a classification, at least six product categories can be distinguished:

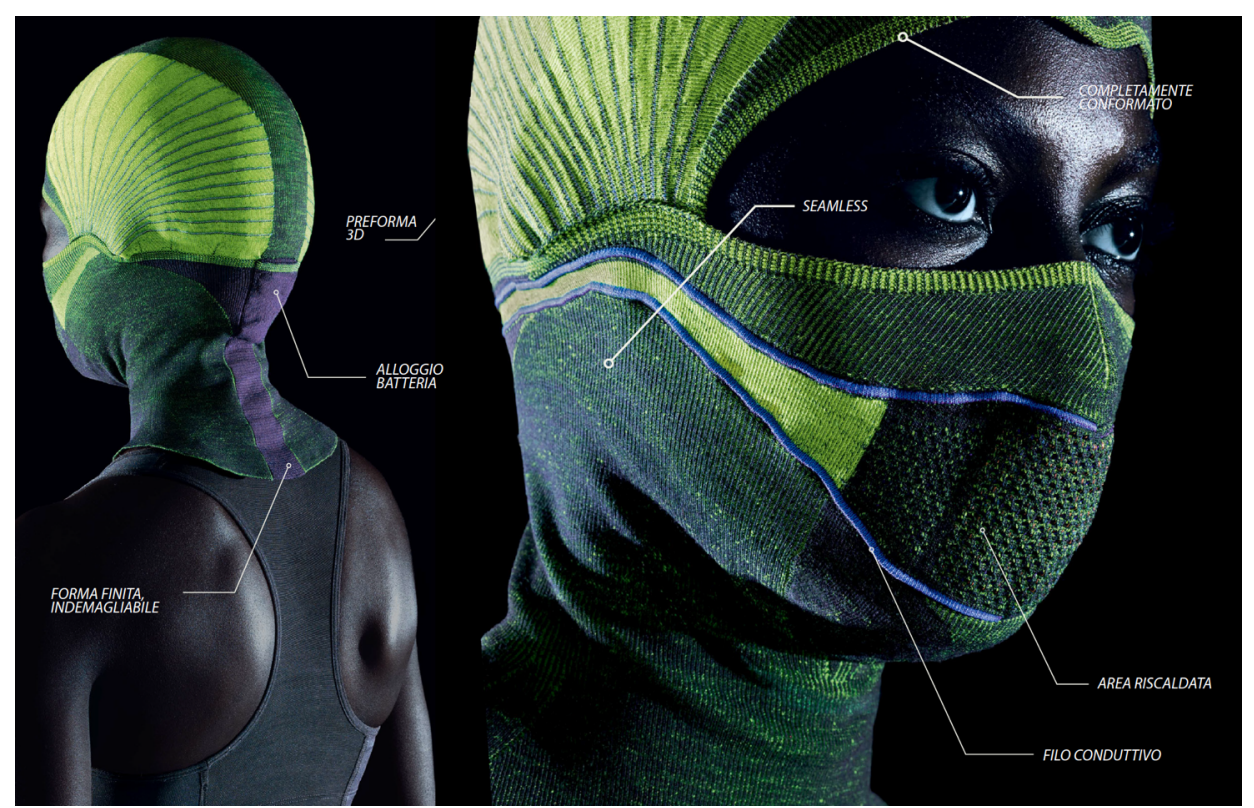

Figure 5: "Our game-changing CMS ADF technology has opened up a whole new world of possibilities in performance knitwear - from heat and moisture control, to compression and 3D pre-shaping - taking traditional fabric construction to another level. Our weave-in and plating applications have boosted the development potential of performance knits even further, resulting in the Performance+ collection.

Welcome to the future". Joerg Hartmann, Stoll internal brochure

\section{- 2D WOVEN 2D FABRICS.}

Fabrics obtained using traditional two-dimensional weaving technology from the weaving of two sets of yarns, warp and weft. Three-dimensional effects are achieved through pleating or weft control technologies. In the former case, permanent, more or less regular folds are formed on the surface of the fabric, while weft control makes it possible to obtain not only three-dimensional patterns on the surface but also shaped pieces.

- 2D WOVEN 2.5D FABRICS.

Fabrics consisting of three sets of yarns, one of which is arranged in the direction of the thickness. Known as pile or double wall fabrics, they are manufactured on traditional looms using selective yarn tensioning techniques and face-to-face weaving.

- 2D WOVEN 3D FABRICS.

More commonly known as multilayer fabrics, these are obtained using a traditional loom to which a third set of yarns is added to act as a "binder" or the weave is structured in such a way that one single set of weft yarns is able to interweave and interconnect several levels of warp yarns.

- 2D WOVEN NON-INTERLACED 3D FABRICS.

These are also multilayer fabrics. However, in this case the sets of yarns, assembled on a traditional loom with a flat configuration are not interlaced with each other.

- 3D WOVEN NON-INTERLACED 3D FABRICS.

Some looms for three-dimensional weaving enable 3D geometrical structures to be created without interlacing the three sets of yarns involved in the manufacture. An example is polar weaving.

- 3D WOVEN 3D FABRICS.

Fabrics in which three sets of yarns arranged orthogonally are completely interlaced by means of a multidirectional shed opening mechanism. this process requires the use of specific machinery and is termed true 3D weaving.

\section{Differences between 3D knitting and 3D weaving}

3D knitting and 3D weaving are two of the technologies most widely used to give textiles threedimensional characteristics. 
However, they differ from each other in fundamental ways, which means that one technology may be more suitable than another for certain purposes.

With 3D knitting it is possible to obtain specific forms. The fabric comes off the machine already formed with the edging already finished (full-fashioned whole garments). With 3D weaving, in contrast, shaping is only possible after the fabric has come off the loom through cutting and hemming.

With regard to the precision of designs, weaving allows for much more precise, well-defined colours and shapes when compared with knitting.

Digital knitting machines make it possible to alternate the various techniques in a single machine while 2D weaving looms do not also allow 3D structures to be obtained.

By their structural nature, knitted garments are intrinsically elastic while woven garments have a rigid structure. This is why 3D weaving is used for the creation of preforms for composites: the interlocking of warp and weft, in combination with fibres such as glass and carbon fibre, mean that it becomes structural and that it can even substitute reinforcing elements in metal.

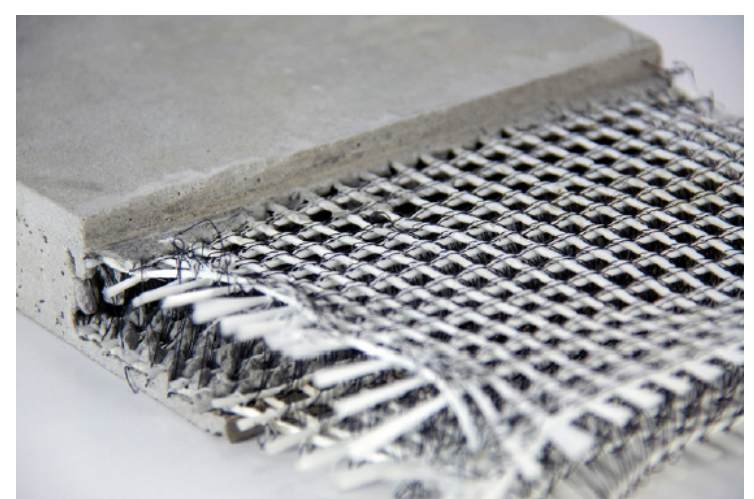

Figure 6: Textile as concrete reinforcement

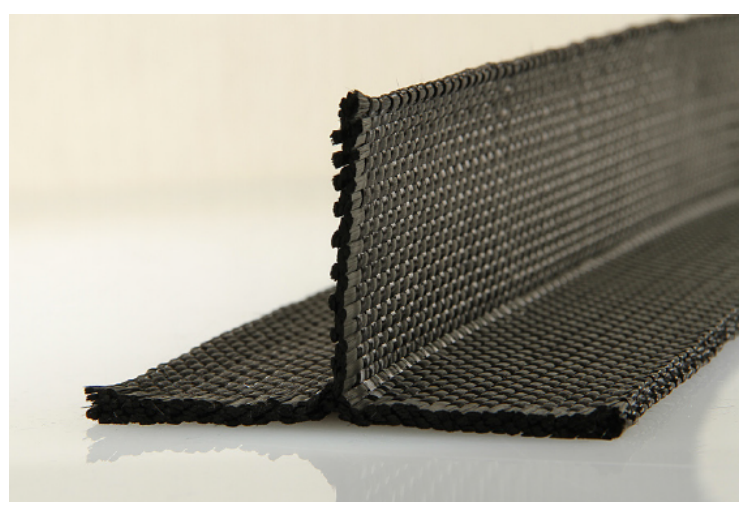

Figure 7: Textile for carbon fibre composite

3D knitting, on the other hand, is excellent for coverings and clothing, as its structure is able to adapt to the contours of the body, while the patterned effect peculiar to knitted fabrics is able to simulate the rigidity of weaving.

\section{Smart knitting. A shoe design case study}

Smart knitting is one of the most innovative manufacturing processes for the creation of more contemporary sports shoes. This type of production process has met with great success among users as the shoes it creates are lighter and more breathable, in addition to displaying the effect of the stitches on the upper part of the shoe. The interaction between looks and functionality is described in the following manner on the Adidas website regarding the Adidas Adizero shoe: "using the latest design tools with our new seamless engineering technology, Adidas has created this first-of-its-kind running shoe, the Adizero Primeknit. While sport shoes are usually made from lots of separate pieces, this breakthrough method digitally knits the entire upper in just one.

"Knitting fused yarn allows us to fine-tune the exact amount of flexibility and support needed in every part of the shoe. This means lightweight comfort that wraps seamlessly around your foot, whilst fewer materials produce less waste." 


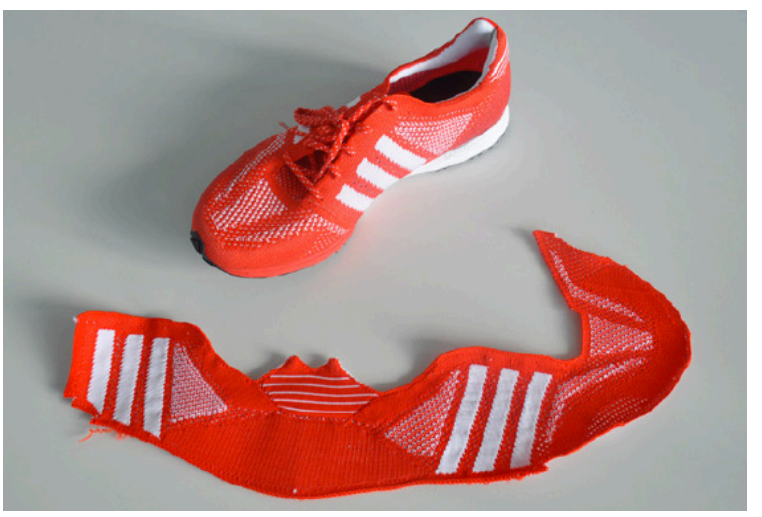

Figure 8: Detail of the shoe obtained using a manual machine

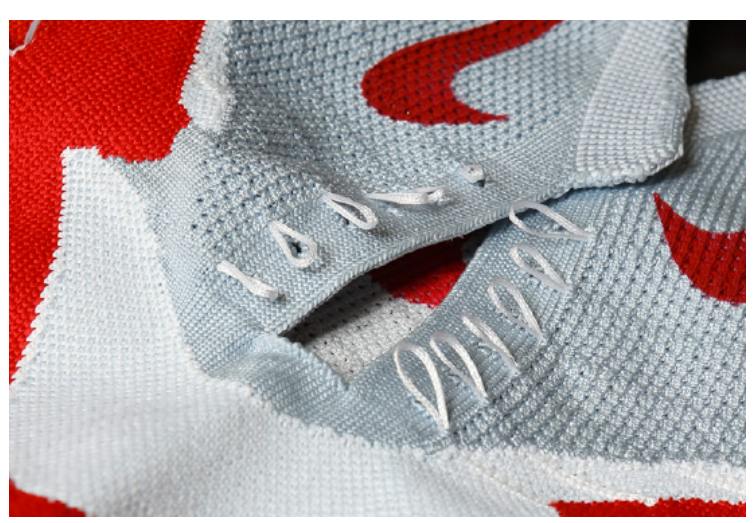

Figure 9: Detail of shoe obtained using an electronic machine

Compared with the steps in the manufacturing process for a traditional shoe, there is a great saving: the great advantage of this technology lies in precisely in the fact that a ready-made upper is obtained in one piece as opposed to needing to sew several pieces together. The steps involved in the manufacture of a shoe using the smart knitting process are the following:

- design

- testing on a sample

- fitting

- choice of yarn

- programming the machine

- closure of upper (sewing)

- fitting to the sole

The production process chain is much shorter and above all free from the defects can occur during manual stitching. This type of apparel, on the other hand, is perfectly reproducible ${ }^{6}$.

What is interesting about the process is that it makes it possible to join the various parts necessary for the upper into a single piece. What was done with the cut-and-sew method through the selection of different fabrics is done in smart knitting not only by choosing different yarns and fibres but also by being able to combine them with each other with structures chosen on an ad hoc basis. This is possible as the machine enables every point, every pixel of fabric to be programmed individually.

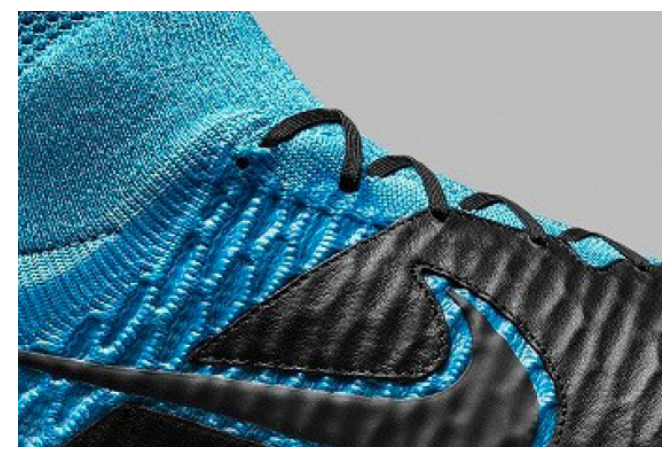

Figure 10: Detail of double jersey created on automatic machine

${ }^{6}$ The only defects which might be encountered are external temperature and machine operation. If the machine is too hot, the needles, being made of metal, could dilate, giving rise to slight differences between the pieces created. 


\subsection{Future innovations and applications}

Recent advances in materials science and the textile industry are lending textiles a new role that makes them potentially suitable for the use of new technologies based on the integration of several disciplines.

The plus point in the textile industry's favour will be the use of technological platforms based on multidisciplinarity, which will lead to a new way of conceiving the use of textiles in the future. For example, in the clothing textile field, the aim is to create garments that behave like a "second skin"; in other words, a shield that is protective and functional at the same time. Currently many research centres are working on developments based on innovative processes and materials, such as the process of plasma treatment, which can modify fabrics on the surface without altering their intrinsic characteristics, thus obtaining additional functionality such as water repellency, hydrophilicity or adhesiveness, or enhancing their antistatic performance, sheen, permeability, biocompatibility or tactility.

Another sector undergoing development is nanotechnologies, which operate at the molecular level, combining principles of chemistry and physics with elements of science and information engineering. The term "nanoproducts" applies to structures with dimensions of less than one hundred nanometres, that is, 800 times smaller than the diameter of a human hair, with totally different properties from those of the same materials but of greater dimensions. Applications and studies currently underway in the textile field regard the creation of materials which have a chameleon effect, are antibacterial, protect against ultraviolet light, are flame retardant, are antistatic, protect against chemicals or are self-cleaning.

Finally, and perhaps the most advanced research frontier, regards clothing which "communicates"; that is, clothing equipped with micro embedded computerised systems which fully integrates with mobile phones, computers, remote health checks, music devices, and so on. ${ }^{7}$

\section{Some possible concluding remarks}

A veritable clothing revolution is taking place and is leading to a new way of dressing, of living daily life, of interpreting materials in a more functional, less superficial way. In this new context, Italian creativity has been able to prove itself by seeking out new approach to textile design, one in which yarns and fibres are combined with different structures and functionalities in order to obtain the necessary performance characteristics.

Currently around $60 \%$ of textile products manufactured globally use fibres which only fifty or sixty years ago were not yet on the market, while according to some analysts $30 \%$ of the products that will be sold in fifty years from now have not even been conceived of yet. According to a survey conducted among researchers all around the world, products that will arrive on the market over the next few decades are expected to feature self-repairing materials, garments equipped with digital devices, smart nanomaterials, and so on.

It is therefore clear what the areas of growth and development are for the industry in the near future. Producing innovation requires trying out new directions that others have not taken yet, exploring new production methods and anticipating changes that are still to come.

The textile sector is proving increasingly to be a research area capable of becoming an ideal arena of experimentation for technology, aesthetics and advanced functionalities. It therefore becomes essential that we completely transform our design approach, no longer separating design from technical knowledge and engineering in the true sense with a view to final product innovation. ${ }^{8}$

${ }^{7}$ Dallo sport alla moda: nuovi trend style, Aldo Tempesti, taken from Forma e Materia, Maggioli Editore, 2012

8 in Design follows materials, M. Ferrara (ed.), S .Lucibello )ed.), Alinea, Florence 2009 


\section{References}

Briggs-Goode A., Townsend K., (eds.), Textile Design: Principles, Advances and Applications, Woodhead Publishing Limited, Philadelphia, 2011

Chen X., Waterton Taylor L., Tsai L., An overview on fabrication of three-dimensional woven textile preforms for composites, Textile Research Journal, January 26, 2011

Conti G.M., Cross Fertilization: un approccio al progetto per la moda, Mondadori Università, ebook, Milan, 2012.

Conti, G.M., Motta, M., Knit Design. Ovvero progettare con un filo, Ottagono, no. 268, March 2014

Conti G.M., Sul filo dell'innovazione. Progetti e visioni tra moda, tessuti, filati in (exhibition catalogue), various authors, Textile Vivant. Percorsi, esperienze e ricerche del textile design, Editoriale Silvana Spa, 2014.

Conti G., Gaddi R., Motta M., 3D technology and industrial design to breathe new life into product design. Is this the future of fashion and textiles? International Conference on Design (CODE 2016), Gurgaon, India

Conti G.M., Mello de Souza P., Cross Fertilization: Um Direcionamento Para A Inovação, 12 ․ Congresso Brasileiro de Pesquisa e Desenvolvimento em Design, Belo Horizonte, Brazil, 2016

D’Ercole M., Rosa G., Industria tessile, Enciclopedia italiana Treccani, Appendix V, 1995

Del Curto B., Marano C., Materiali per il design, introduzione ai materiali e alle loro proprietà, Ambrosiana, 2012

Durante, V., Sportsystem, the Fashion Performance. Caerano San Marco; Danilo Zanetti Editore, 2004

Fiorani, E., I panorami del contemporaneo, Milan, Lupetti, 2005

Frassine R., Soldati M.G., Rubertelli M., Textile design. Materiali e tecnologie, Franco Angeli, Milan, 2015

Horrocks A. R., Anand S. C., Handbook of Technical Textiles, The Textile Institute, Woodhead Publishing Limited, England, 2000

Redi G., Tessuto tra le due e le tre dimensioni, Politecnico di Milano, 2014

Ricchetti M., Moda. Neomateriali nell'economia circolare, Edizioni Ambiente, Milan, 2017

Unal P. G., 3D Woven Fabrics, Namuk Kemal University Department of Textile Engineering, Turkey, 2012

San Martin, M., Materiali innovativi per la moda, Modena, Logos 2010

Shukla A., 3D Fabric and Its Application in Clothing, Indian Institute of Technology, Delhi, 2013 